\title{
PENGEMBANGAN MEDIA PEMBELAJARAN DIGITAL DAILY ASSESSMENT BAGI MAHASISWA PROGRAM STUDI PENDIDIKAN BIOLOGI IKIP BUDI UTOMO MALANG
}

\author{
Ardian Anjar Pangestuti ${ }^{1}$, Erfitra Rezqi Prasmala ${ }^{2}$ \\ 1,2 Program Studi Pendidikan Biologi, IKIP Budi Utomo Malang, Malang, Indonesia \\ E-mail: ardianpangestuti@gmail.com
}

\begin{abstract}
Metacognitive skill is one of the skills that students must have because this skill can support students' success in achieving their learning goals. Based on the results of observation and several studies conducted in Biology Education Study Program, it can be seen that students' metacognitive is still low. This condition eventually led the students' cognitive learning outcome low. Therefore, it needed an effort to empower the students' metacognitive skill and cognitive learning outcome. One of the efforts that could be done was developing Digital Daily Assessment learning media. The values obtained from the validation results were as follows: validation value from the material expert was $95.14 \%$, validation value from the media expert was $97.92 \%$, validation value from the practitioner was $97.25 \%$, and the value obtained from the readability test results involving Biology Education Study Program students was 93.4\%. Based on the results of the validation, it can be seen that Digital Daily Assessment learning media is suitable for learning activities.
\end{abstract}

Keywords: Digital Daily Assessment, Metacognitive Skills

\begin{abstract}
Abstrak Keterampilan metakognitif adalah salah satu keterampilan yang harus dimiliki oleh mahasiswa, karena keterampilan ini dapat mendukung keberhasilan mahasiswa dalam mencapai tujuan belajarnya. Berdasarkan hasil observasi dan hasil beberapa penelitian yang dilakukan di Program Studi Pendidikan Biologi dapat diketahui bahwa metakognitif mahasiswa masih rendah. Kondisi ini pada akhirnya menyebabkan hasil belajar kognitif mahasiswa rendah. Oleh karena itu, perlu dilakukan sebuah upaya untuk memberdayakan keterampilan metakognitif dan hasil belajar kognitif mahasiswa. Salah satu upaya yang dapat dilakukan adalah dengan mengembangkan media pembelajaran Digital Daily Assessment. Berikut ini nilai yang diperoleh dari hasil validasi, nilai validasi oleh ahli materi adalah 95,14\%, nilai validasi oleh ahli media adalah 97,92\%, nilai validasi oleh praktisi adalah 97,25\%, dan nilai yang diperoleh dari hasil uji keterbacaan yang melibatkan mahasiswa Program Studi Pendidikan Biologi adalah 93,4\%. Berdasarkan hasil validasi tersebut dapat diketahui bahwa media pembelajaran Digital Daily Assessment layak digunakan untuk kegiatan pembelajaran
\end{abstract}

Kata kunci: Digital Daily Assessment, Keterampilan Metakognitif

Sebagaimana kita ketahui bersama bahwa saat ini telah memasuki abad ke 21 . Pada abad ini, setiap orang dituntut untuk memiliki kemampuan untuk menjadi pribadi yang memiliki inisiatif yang tinggi, bertanggung jawab, berani mengambil resiko, berpikir kreatif dan inovatif, berpikir kritis, pemecahan masalah, ulet, memiliki keterampilan sosial yang baik, memiliki keterampilan metakognitif, dll. (Barnes, 2007 \& Scott, 2015). Seluruh kemampuan itu dikenal dengan kecakapan hidup abad 21.

Berdasarkan atas jenis-jenis kecakapan yang telah disampaikan sebelumnya, ada sebuah kecakapan yang memiliki peran penting untuk mendukung keberhasilan seseorang, kecakapan tersebut adalah keterampilan metakognitif. Menurut Livingston (1997) metakognisi adalah kemampuan berpikir tingkat tinggi yang melibatkan kontrol aktif pada proses kognitif yang terlibat pada kegiatan pembelajaran. 
Lantas, bagaimana dengan keterampilan metakognitif mahasiswa IKIP Budi Utomo Malang? Berdasarkan hasil observasi pembelajaran yang dilakukan pada program studi pendidikan Biologi di IKIP Budi Utomo Malang, diketahui bahwa masih sangat jarang sekali proses pembelajaran yang dilakukan dosen pengampu untuk memberdayakan keterampilan metakognitif. Proses pembelajaran dilakukan dengan menggunakan metode ceramah, praktikum, dan diskusi sederhana ataupun dengan menggunakan model pembelajaran tertentu. Model pembelajaran yang biasa diterapkan belum mampu memberdayakan keterampilan metakognitif. Gejala yang dapat diamati dari kondisi ini adalah mahasiswa sering terlambat mengumpulkan tugas atau bahkan ada beberapa mahasiswa yang tidak mengumpulkan tugas. Mahasiswa sering datang terlambat pada perkuliahan. Kondisi ini masih terus terjadi meskipun mahasiswa telah dimotivasi oleh dosen pengampu. Hal ini menandakan bahwa mahasiswa belum dapat mengontrol proses belajarnya. Berbagai hal tersebut berpengaruh pada hasil belajar mahasiswa. Rata-rata nilai UAS pada mata kuliah Biologi Umum adalah 69,4; pada matakuliah Biokimia adalah 63; dan pada mata kuliah taksonomi tumbuhan adalah 56,3. Kondisi serupa juga terjadi pada mata kuliah lainnya.

Hasil tersebut dikuatkan oleh hasil penelitian yang dilakukan oleh beberapa dosen pengampu mata kuliah di Program Studi Pendidikan Biologi IKIP Budi Utomo Malang. Penelitian yang dilakukan Setiawan (2015) menunjukkan bahwa belum ada kegiatan pembelajaran untuk memberdayakan kemampuan metakognitif mahasiswa Program Studi Pendidikan Biologi kelas C angkatan 2014. Hal ini tentunya berdampak pada kemampuan metakognitif mahasiswa. Presentase kemampuan metakognitif mahasiswa sebesar 69\%. Penelitian lainnya dilakukan Lestari \& Wijayanti (2016) dengan hasil sebanyak $17 \%$ mahasiswa kelas $\mathrm{B}, \mathrm{D}, \mathrm{E}, \mathrm{F}$ angkatan 2013 mendapatkan rata-rata nilai metakognisi dengan rentang (86 - 100), sebanyak $26 \%$ mahasiswa mendapatkan ratarata nilai metakognisi dengan rentang (70 85), dan sebanyak $67 \%$ mahasiswa mendapatkan nilai dibawah 70. Berdasasarkan hasil penelitian tersebut diketahui bahwa metakognitif mahasiswa Program Studi Pendidikan Biologi masih rendah.

Berdasarkan hal yang telah disampaikan sebelumnya, maka harus segera dilakukan sebuah upaya untuk memberdayakan keterampilan metakognitif. Scott (2015) menyatakan bahwa upaya untuk memberdayakan kecakapan hidup abad 21 dapat dilakukan tanpa menunggu siswa mencapai jenjang pendidikan tinggi, namun sangat penting untuk memberikan dukungan kepada siswa untuk menumbuhkan kompetensi dan keterampilan metakognitif dari tahap awal pendidikan formal. Jika sumber tersebut menyatakan bahwa kompetensi dan keterampilan metakognitif sangat penting ditumbuhkan sejak dari tahap awal pendidikan formal, maka pemberdayaan metakognitif bagi mahasiswa menjadi hal yang urgent untuk dilakukan saat ini. Alasan lainnya agar kegiatan belajar yang dilakukan oleh mahasiswa dapat optimal serta memberikan hasil yang memuaskan. Livingston (1997) menyatakan bahwa, pada suatu proses pembelajaran metakognisi memegang salah-satu peranan kritis (sangat penting) agar pembelajaran berhasil. Berdasarkan pernyataan tersebut dapat diketahui bahwa, jika keterampilan metakognitif mahasiswa berkembang dengan baik maka hasil belajar kognitif mahasiswa juga akan meningkat.

Berangkat dari permasalahan yang telah disampaikan sebelumnya, maka perlu dilakukan sebuah upaya untuk mengembangkan media pembelajaran Digital Daily Assessment. Media pembelajaran ini diharapkan dapat memberdayakan keterampilan metakognitif mahasiwa. Jika keterampilan metakognitif mahasiswa meningkat, diharapkan pula hasil belajar kognitif mahasiswa juga akan meningkat.

$$
\text { Digital Daily Assesment merupakan }
$$


media pembelajaran digital yang membantu siswa untuk merencanakan, memonitor, dan mengevaluasi kegiatan belajar siswa. Selanjutnya, pada artikel ini akan dibahas tentang tahapan pengembangan media pembelajaran Digital Daily Assessment.

\section{METODE}

Model pengembangan yang digunakan dalam penelitian ini adalah 4D menurut Thiagarajan dkk. (1974). Tahapan yang harus dilalui dalam pengembangan terdiri atas, tahap define, design, develop, dan disseminate. Berikut ini penjelasan untuk masing-masing tahapan pengembangan

Tahap pertama adalah define. Pada tahap ini dilakukan analisis awal untuk menetapkan dan menjelaskan kebutuhan dalam pembelajaran sehingga perlu dilakukan suatu penelitian pengembangan. Kegiatan yang dilakukan pada tahap ini sebagai berikut. Pertama, melakukan wawancara dengan beberapa dosen di program studi pendidikan Biologi. Tujuannya untuk memperoleh data terkait proses pembelajaran di kelas, sikap mahasiswa dalam mengikuti perkuliahan, dan hasil belajar kognitif. Kedua, mengidentifikasi keterampilan metakognitif mahasiswa dengan memberikan soal tes. Ketiga, melakukan analisis kurikulum untuk menetapkan Capaian Pembelajaran, kemampuan akhir yang direncanakan, dan indikator pembelajaran yang harus dikuasai mahasiswa. Keempat, menyusun RPS (Rencana Pembelajaran Semester) dan RPP (Rencana Pelaksanaan Pembelajaran)

Tahap kedua adalah design. Pada tahap ini akan dilakukan penyusunan purwarupa media pembelajaran Digital Daily Assessment. Beberapa kegiatan yang dilakukan pada tahap ini sebagai berikut. Pertama, menyusun draft rancangan media pembelajaran Digital Daily Assesment. Kedua, membuat protype media pembelajaran Digital Daily Assesment. Ketiga, memuat media pembelajaran agar dapat diakses melalui Smart phone ataupun komputer.

Tahap ketiga adalah develop. Tahap ini merupakan tahapan untuk memodifikasi purwarupa media pembelajaran berdasarkan umpan balik yang didapatkan dari hasil validasi dan uji coba skala kecil. Kegiatan pada tahap ini antara lain: mengujikan produk kepada validator, validator dalam penelitian pengembangan ini adalah ahli materi, ahli media pembelajaran, dan praktisi; merevisi produk berdasarkan hasil validasi; dan melakukan uji keterbacaan. Subyek dalam uji keterbacaan ini adalah mahasiswa program studi pendidikan Biologi, sebanyak 15 mahasiswa.

Tahap terakhir adalah disseminate, merupakan langkah yang ditempuh untuk menyebarluaskan media pembelajaran Digital Daily Assessment. Pada tahap ini akan dilakukan kegiatan validasi lanjut, yaitu mengujikan produk kepada validator, yaitu ahli materi, ahli media pembelajaran, dan praktisi. Selain itu, akan dilakukan pula uji coba skala besar. Subyek dalam uji coba ini adalah mahasiswa program studi pendidikan Biologi, sebanyak 40 mahasiswa. Tahap terakhir adalah penyebaran media pembelajaran Digital Daily Assessment.

Instrumen pengumpulan data yang digunakan pada penelitian ini sebagai berikut. Pertama, soal tes keterampilan metakognitif terintegrasi dengan soal essay. Soal ini digunakan untuk mengidentifikasi keterampilan metakognitif mahasiswa pada kegiatan awal penelitian (pada tahap define). Kedua, instrumen validasi kelayakan materi. Instrumen ini merupakan instrumen yang digunakan untuk mengukur tingkat validitas media pembelajaran jika dilihat dari segi materi. Ketiga, instrumen validasi kelayakan media. Instrumen ini digunakan oleh ahli media untuk mengukur tingkat validitas media pembelajaran. Keempat, instrumen validasi oleh praktisi. Instrumen ini digunakan untuk mengetahui tingkat kesesuaian media pembelajaran untuk diterapkan dalam kegiatan pembelajaran. Instrumen ini akan diisi oleh praktisi, dalam hal ini yang bertindak sebagai praktisi adalah dosen yang pernah mengajar mata kuliah Morfologi Tumbuhan. Kelima, angket respon mahasiswa terhadap media 
pembelajaran Digital Daily Assessment. diisi oleh mahasiswa pada kegiatan uji keterbacaan. Keenam, rubrik penilaian keterampilan metakognitif terintegrasi soal essay. Rubrik penilaian ini dikembangkan oleh Corebima (2009), serta digunakan untuk mengukur keterampilan metakognitif mahasiswa.

Kegiatan analisis data dilakukan dengan menghitung skor yang diberikan oleh setiap validator pada masing-masing lembar validasi. Selanjutnya, dari skor yang telah diperoleh dihitung rata-rata pada masingmasing aspek kemudian diubah dalam bentuk persen dengan mengikuti rumus berikut ini.
Instrumen ini berbentuk angket dan akan

$$
\mathrm{P}=\frac{\sum x}{\sum x 1} 100 \%
$$

Keterangan

$\mathrm{P} \quad=$ persentase

$\sum \mathrm{X}=$ jumlah jawaban seluruh responden dalam satu item pertanyaan

$\sum \mathrm{X}_{1} \quad=$ jumlah jawaban ideal dalam satu item

$100 \%=$ konstanta

Selanjutnya skor yang diperoleh dari hasil penghitungan ditentukan tingkat validitasnya dengan merujuk pada kriteria kevalidan data angket penilaian validator menurut Suwastono (2011) yang tersaji pada Tabel 1.

Tabel 1 Kriteria Kevalidan Data Angket Penilaian Validator

\begin{tabular}{cc}
\hline Skala nilai $(100 \%)$ & Keterangan \\
\hline $81-100$ & Sangat valid (tidak revisi) \\
$61-80$ & Valid (tidak revisi) \\
$41-60$ & Cukup valid (revisi) \\
$21-40$ & Kurang valid (revisi) \\
$0-20$ & Sangat tidak valid (revisi) \\
\hline
\end{tabular}

\section{HASIL}

\section{Tahap Define}

Salah satu hal yang dilakukan pada tahap ini adalah memberikan soal tes keterampilan metakognitif terintegrasi soal essay. Tujuan kegiatan ini adalah untuk mengidentifikasi

keterampilan metakognitif mahasiswa. Rubrik penilaian keterampilan metakognitif ini sesuai dengan Corebima (2009). Hasil tes tersaji pada Tabel 2.

Tabel 2. Hasil Tes Uji Keterampilan Metakognitif Mahasiswa Program Studi Pendidikan Biologi

\begin{tabular}{|c|l|c|}
\hline Skor & \multicolumn{1}{|c|}{ Kriteria Skor } & $\begin{array}{c}\text { Persentase } \\
(\%)\end{array}$ \\
\hline 0 & Mahasiswa tidak menuliskan jawaban sama sekali & 0 \\
\hline 1 & $\begin{array}{l}\text { Mahasiswa tidak menuliskan jawaban dengan menggunakan kalimat } \\
\text { sendiri, urutan jawaban kurang/tidak runtut dan sistematis, jawaban } \\
\text { kurang/ tidak logis, jawaban menggunakan gramatika (bahasa) yang } \\
\text { tidak benar, jawaban tidak dilengkapi dengan alasan } \\
\text { (analisis/evaluasi/kreasi), dan jawaban yang dituliskan tidak benar. }\end{array}$ & 0 \\
\hline 2 & $\begin{array}{l}\text { Mahasiswa tidak menuliskan jawaban dengan menggunakan kalimat } \\
\text { sendiri, urutan jawaban kurang/tidak runtut dan sistematis, jawaban } \\
\text { kurang/ tidak logis, jawaban menggunakan gramatika (bahasa) yang } \\
\text { kurang benar, jawaban kurang dilengkapi dengan alasan } \\
\text { (analisis/evaluasi/kreasi), dan jawaban yang dituliskan kurang benar. }\end{array}$ & 73,08 \\
\hline 3 & $\begin{array}{l}\text { Mahasiswa tidak menuliskan jawaban dengan menggunakan kalimat } \\
\text { sendiri, urutan jawaban kurang/tidak runtut dan sistematis, jawaban }\end{array}$ & 0 \\
\hline
\end{tabular}




\begin{tabular}{|c|l|c|}
\hline & $\begin{array}{l}\text { kurang/ tidak logis, jawaban menggunakan gramatika (bahasa) kurang } \\
\text { benar, jawaban dilengkapi dengan alasan (analisis/evaluasi/kreasi), } \\
\text { dan jawaban yang dituliskan benar. }\end{array}$ & 11,5 \\
\hline 4 & $\begin{array}{l}\text { Mahasiswa tidak menuliskan jawaban dengan menggunakan kalimat } \\
\text { sendiri, urutan jawaban runtut dan sistematis, jawaban yang dituliskan } \\
\text { logis, jawaban menggunakan gramatika (bahasa) yang benar, jawaban } \\
\text { dilengkapi dengan alasan (analisis/evaluasi/kreasi), dan jawaban yang } \\
\text { dituliskan benar. }\end{array}$ & $\begin{array}{l}\text { Mahasiswa menuliskan jawaban dengan menggunakan kalimat sendiri, } \\
\text { urutan jawaban kurang/ tidak runtut dan sistematis, jawaban yang } \\
\text { dituliskan kurang/tidak logis, jawaban menggunakan gramatika } \\
\text { (bahasa) kurang benar, jawaban dilengkapi dengan alasan } \\
\text { (analisis/evaluasi/kreasi), dan jawaban yang dituliskan benar. }\end{array}$ \\
\hline 6 & $\begin{array}{l}\text { Mahasiswa menuliskan jawaban dengan menggunakan kalimat sendiri, } \\
\text { urutan jawaban runtut dan sistematis, jawaban yang dituliskan } \\
\text { kurang/tidak logis, jawaban menggunakan gramatika (bahasa) yang } \\
\text { kurang benar, jawaban dilengkapi dengan alasan } \\
\text { (analisis/evaluasi/kreasi), dan jawaban yang dituliskan benar. }\end{array}$ & 3,9 \\
\hline 7 & $\begin{array}{l}\text { Mahasiswa menuliskan jawaban dengan menggunakan kalimat sendiri, } \\
\text { urutan jawaban runtut dan sistematis, jawaban yang dituliskan logis, } \\
\text { jawaban menggunakan gramatika (bahasa) yang benar, jawaban } \\
\text { dilengkapi dengan alasan (analisis/evaluasi/kreasi), dan jawaban yang } \\
\text { dituliskan benar. }\end{array}$ & 0 \\
\hline
\end{tabular}

\section{Tahap Design}

Pada tahap ini dilakukan penyusunan draft menunjukkan sebagian tampilan media media pembelajaran dan memuat media pembelajaran Digital Daily Assessment. pembelajaran tersebut di edmodo. Gambar 1

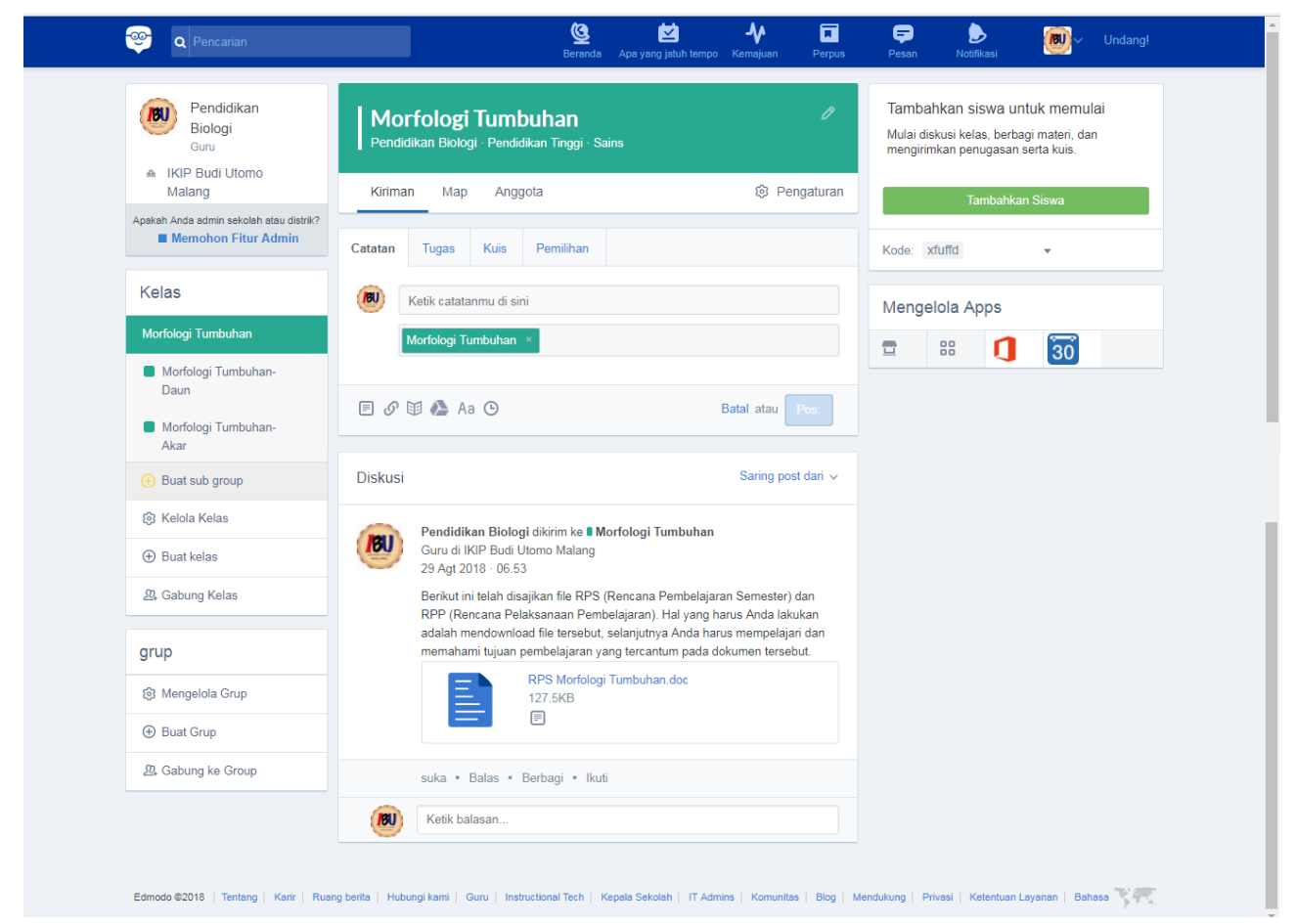

Gambar 1. Tampilan Media Pembelajaran Digital Daily Assessment pada Edmodo 


\section{Tahap Develop}

Pada tahap ini media pembelajaran akan diujikan kepada validator ahli materi, ahli media, dan praktisi. Akan dilakukan pula uji keterbacaan yang melibatkan mahasiswa.
Oleh karena itu, pada bagian ini akan dipaparkan data hasil validasi dan uji keterbacaan. Hasil validasi oleh ahli materi tersaji pada 3.

Tabel 3. Ringkasan Hasil Validasi Ahli Materi Morfologi Tumbuhan

\begin{tabular}{|l|l|c|c|}
\hline \multicolumn{2}{|c|}{ SUB KOMPONEN } & $\begin{array}{c}\text { PERSENTASE } \\
\text { SKOR YANG } \\
\text { DIPEROLEH }\end{array}$ & KETERANGAN \\
\hline \multicolumn{2}{|c|}{ KELAYAKAN ISI } & & Sangat Valid \\
\hline A & $\begin{array}{l}\text { Kesesuaian uraian materi dengan Capaian } \\
\text { Pembelajaran Mata Kuliah (CP-MK) }\end{array}$ & $91,67 \%$ & Sangat Valid \\
\hline B & Keakuratan materi & $100 \%$ & Sangat Valid \\
\hline C & Materi pendukung praktik & $100 \%$ & Sangat Valid \\
\hline \multicolumn{2}{|c|}{ KELAYAKAN PENYAJIAN } & $91,67 \%$ & Sangat Valid \\
\hline D & Teknik penyajian & $87,5 \%$ & Sangat Valid \\
\hline E & Penyajian pembelajaran & $100 \%$ & Sangat Valid \\
\hline F & Kelengkapan penyajian & $95,14 \%$ & \\
\hline & \multicolumn{2}{|c|}{ RATA-RATA }
\end{tabular}

Tabel 4 menyajikan data hasil validasi oleh ahli media pembelajaran.

Tabel 4. Ringkasan Hasil Validasi Ahli Media Pembelajaran

\begin{tabular}{|c|c|c|c|}
\hline & INDIKATOR PENILAIAN & $\begin{array}{l}\text { PERSENTASE } \\
\text { SKOR YANG } \\
\text { DIPEROLEH }\end{array}$ & KETERANGAN \\
\hline A & \multicolumn{2}{|l|}{ KELAYAKAN ISI } & \\
\hline 1 & Kebermaknaan Media & $91,67 \%$ & Sangat Valid \\
\hline 2 & Penulisan Naskah Media & $100 \%$ & Sangat Valid \\
\hline $\mathrm{B}$ & TATA BAHASA & $100 \%$ & Sangat Valid \\
\hline $\mathrm{C}$ & TAMPILAN MEDIA & $100 \%$ & Sangat Valid \\
\hline & RATA-RATA & $97,92 \%$ & Sangat Valid \\
\hline
\end{tabular}

Tabel 5 menyajikan data hasil validasi praktisi.

Tabel 5. Ringkasan Hasil Validasi Praktisi

\begin{tabular}{|c|l|c|c|}
\hline & \multicolumn{1}{|c|}{ INDIKATOR PENILAIAN } & $\begin{array}{c}\text { PERSENTASE } \\
\text { SKOR YANG } \\
\text { DIPEROLEH }\end{array}$ & KETERANGAN \\
\hline 1 & $\begin{array}{l}\text { Kesesuaian dengan Capaian } \\
\text { Pembelajaran yang ingin dicapai }\end{array}$ & $100 \%$ & Sangat Valid \\
\hline 2 & $\begin{array}{l}\text { Kesesuaian Media Pembelajaran untuk } \\
\text { Ditetepakan dalam Pembelajaran }\end{array}$ & $95 \%$ & Sangat Valid \\
\hline 3 & Soal Evaluasi & $94 \%$ & Sangat Valid \\
\hline 4 & $\begin{array}{l}\text { Kesesuaian dengan tingkat perkembangan } \\
\text { peserta didik }\end{array}$ & $100 \%$ & Sangat Valid \\
\hline \multicolumn{1}{|l}{ RATA-RATA } & $97,25 \%$ & Sangat Valid \\
\hline
\end{tabular}


Tahap 6 menyajikan data hasil uji keterbacaan yang meilbatkan mahasiswa Program Studi Pendidikan Biologi.

Tabel 6. Hasil Uji Keterbacaan oleh Mahasiswa Program Studi Pendidikan Biologi

\begin{tabular}{|c|c|c|c|c|c|c|}
\hline \multirow[b]{2}{*}{ No. } & \multirow{2}{*}{$\begin{array}{c}\text { NAMA } \\
\text { MAHASISWA }\end{array}$} & \multicolumn{3}{|c|}{ ASPEK PENILAIAN } & \multirow{2}{*}{$\begin{array}{l}\text { RATA- } \\
\text { RATA }\end{array}$} & \multirow[b]{2}{*}{ KETERANGAN } \\
\hline & & Tampilan & $\begin{array}{c}\text { Penyajian } \\
\text { Materi }\end{array}$ & Manfaat & & \\
\hline 1. & Mahasiswa A & 100,0 & 97,5 & 100,0 & 99,2 & Sangat Valid \\
\hline 2. & Mahasiswa B & 100,0 & 97,5 & 100,0 & 99,2 & Sangat Valid \\
\hline 3. & Mahasiswa C & 95,8 & 97,5 & 95,8 & 96,4 & Sangat Valid \\
\hline 4. & Mahasiswa D & 95,8 & 85 & 87,5 & 89,4 & Sangat Valid \\
\hline 5. & Mahasiswa E & 100,0 & 97,5 & 91,7 & 96,4 & Sangat Valid \\
\hline 6. & Mahasiswa F & 91,7 & 92,5 & 95,8 & 93,3 & Sangat Valid \\
\hline 7. & Mahasiswa $\mathrm{G}$ & 95,8 & 95 & 100,0 & 96,9 & Sangat Valid \\
\hline 8. & Mahasiswa H & 91,7 & 87,5 & 95,8 & 91,7 & Sangat Valid \\
\hline 9. & Mahasiswa I & 95,8 & 95 & 100,0 & 96,9 & Sangat Valid \\
\hline 10. & Mahasiswa J & 91,7 & 90 & 87,5 & 89,7 & Sangat Valid \\
\hline 11. & Mahasiswa K & 95,8 & 77,5 & 100,0 & 91,1 & Sangat Valid \\
\hline 12. & Mahasiswa L & 83,3 & 92,5 & 75,0 & 83,6 & Sangat Valid \\
\hline 13. & Mahasiswa M & 95,8 & 97,5 & 95,8 & 96,4 & Sangat Valid \\
\hline 14. & Mahasiswa N & 79,2 & 87,5 & 95,8 & 87,5 & Sangat Valid \\
\hline 15. & Mahasiswa $\mathrm{O}$ & 100,0 & 100 & 100,0 & 100,0 & Sangat Valid \\
\hline \multicolumn{2}{|c|}{ RATA-RATA } & 93,6 & 91,8 & 94,7 & 93,4 & Sangat Valid \\
\hline
\end{tabular}

\section{PEMBAHASAN}

\section{Tahap Define}

Tahap awal pada penelitian ini adalah melakukan observasi dan wawancara dengan dosen di Program Studi Pendidikan Biologi. Tujuan dilakukannya kegiatan ini adalah untuk memperoleh informasi terkait proses pembelajaran di kelas, sikap mahasiswa selama mengikuti kegiatan perkuliahan, dan hasil belajar kognitif mahasiswa. Berikut ini data yang diperoleh dari kegiatan tersebut.

a. Belum tersedia media pembelajaran digital untuk mata kuliah morfologi tumbuhan

b. Kegiatan pembelajaran selama ini dilaksanakan melalui kegiatan diskusi kelompok, persentasi kelompok, dan praktikum.

c. Mahasiswa belum dapat merencanakan kegiatan pembelajaran dengan baik. Hal ini dibuktikan dari adanya siswa yang terlambat datang kuliah dengan alasan bangun kesiangan, mahasiswa yang terlambat mengumpulkan tugas, dan ada pula mahasiswa yang pada saat mengikuti kegiatan praktikum tidak membawa bahan praktikum. d. Rata-rata nilai UTS dan UAS mahasiswa kelas B angkatan 2016 pada mata kuliah Botani sebagai berikut. Rata-rata nilai UTSnya adalah 61,58 , sedangkan rata-rata nilai UAS adalah 54,45.

Berdasarkan data hasil observasi dan wawancara yang telah dipaparkan sebelumnya, dapat diketahui bahwa belum ada upaya yang secara sengaja dilakukan oleh dosen untuk memberdayakan keterampilan metakognitif mahasiswa. Selain itu, sikap yang ditunjukkan mahasiswa selama mengikuti kegiatan pembelajaran menandakan bahwa mahasiswa belum dapat merencanakan dan memonitor kegiatan belajarnya dengan baik. Dampak dari semua itu adalah hasil belajar kognitif mahasiswa rendah.

Selain melakukan kegiatan observasi dan wawancara, dilakukan pula kegiatan untuk mendeteksi keterampilan metakognitif mahasiswa. Kegiatan ini dilaksanakan dengan memberikan soal tes keterampilan metakognitif terintegrasi soal essay. Soal tersebut diberikan kepada mahasiswa kelas B angkatan 2016 yang sedang menempuh mata 
kuliah Botani.

Selanjutnya dilakukan analisis data atas jawaban soal tes mahasiswa. Analisis data dilakukan dengan mencocokkan jawaban siswa dengan rubrik penilaian keterampilan metakognitif terintegrasi soal essay menurut Corebima (2009). Ringkasan Data hasil tes keterampilan metakognitif mahasiswa tersaji pada Tabel 2.

Berdasarkan hasil analisis data diketahui bahwa sebanyak $73,07 \%$ mahasiswa masuk pada tingkatan kriteria 2, sebanyak $11,5 \%$ mahasiswa masuk pada tingkatan 4 dan 5, dan sebanyak 3,9\% mahasiswa masuk pada tingkatan 6. Hal ini berarti sebagian besar mahasiswa tidak dapat menuliskan jawaban dengan menggunakan kalimat sendiri, urutan jawaban yang diberikan kurang/tidak runtut dan sistematis, jawaban mahasiswa kurang/ tidak logis, jawaban yang diberikan menggunakan gramatika yang kurang benar, jawaban kurang dilengkapi dengan alasan berupa hasil analisis atau evaluasi atau kreasi, dan jawaban yang dituliskan kurang benar (Corebima, 2009). Berdasarkan hasil kegiatan observasi, wawancara, dan tes keterampilan metakognitif diketahui bahwa, keterampilan metakognitif mahasiswa rendah, sehingga diperlukan kegiatan pembelajaran yang dapat memberdayakan keterampilan metakognitif mahasiswa.

Kegiatan pengembangan media pembelajaran Digital Daily Assessment dilakukan dengan mengacu pada kurikulum Program Studi Pendidikan Biologi. Dengan demikian, pengembangan media pembelajaran ini tidak menyimpang dari Capaian Pembelajaran yang telah ditetapkan di Program Studi. Berdasarkan hal tersebut, maka kegiatan yang dilakukan selanjutnya adalah menganalisis Capaian Pembelajaran dan dilanjutkan dengan penjabaran indikator dan tujuan pembelajaran. Jika hal tersebut telah dilaksanakan, selanjutnya dilakukan penyusunan RPS dan RPP.

\section{Tahap Design}

Pada tahap ini dilakukan perancangan dan penyusunan draft media pembelajaran Digi- tal Daily Assessment. Draft yang dikembangkan disesuaikan dengan RPS mata kuliah Morfologi Tumbuhan. Media Pembelajaran ini berisi dua materi besar, yaitu Daun dan Akar.

Komponen keterampilan metakognitif menurut Livingston (1997) antara lain: planning (perencanaan), monitoring (monitor), dan evaluating (evaluasi). Berdasarkan hal itu, maka pengembangan media pembelajaran Digital Daily Assessment merujuk pada tiga komponen keterampilan metakognitif tersebut. Dengan demikian, media pembelajaran ini terdiri atas tiga komponen utama tersebut yang selanjutnya kami sebut dengan istilah tahap, karena setiap komponen tersebut akan dilalui oleh mahasiswa sebagai sebuah tahap pembelajaran. Berikut akan disampaikan penjelasan untuk masingmasing tahap pembelajaran.

Pertama adalah tahap planning. Tahap ini diikuti mahasiswa sebelum mulai mempelajari materi tertentu. Komponen yang terdapat pada tahap ini antara lain: rumusan tujuan belajar yang ingin dicapai mahasiswa, RPS, RPP, soal Pre Test, dan pertanyaan yang menuntun mahasiswa untuk menetapkan strategi belajar yang akan mereka lakukan. Dasar pengembangan kegiatan pada tahap ini merujuk pada yang disampaikan Livingston (1997), planning adalah kegiatan untuk menetapkan tujuan belajar, urutan belajar, strategi belajar, dan harapan saat belajar.

Kedua adalah tahap monitoring. Sebagaimana namanya, maka pada tahap ini mahasiswa diarahkan untuk memantau kemajuan belajarnya. Oleh karena itu, pada tahap ini mahasiswa akan diberikan beberapa pertanyaan yang dapat memastikan bahwa strategi yang mereka tempuh pada saat belajar telah sesuai dengan yang mereka rencanakan pada tahap planning, sehingga dapat mendukung keberhasilan belajarnya. Kegiatan ini dilaksanakan pada saat mahasiswa mengikuti kegiatan pembelajaran di kelas.

Terakhir adalah tahap evaluating. Menurut Livingston (1997), kegiatan ini bertujuan agar siswa dapat mengevaluasi proses belajar yang telah mereka lalui. Oleh 
karena itu, pada tahap ini mahasiswa akan mendapatkan soal post test. Selain itu, mahasiswa juga akan mendapatkan pertanyaan-pertanyaan yang memungkinkan mahasiswa dapat mengevaluasi ketepatan strategi belajar yang telah mereka lalui serta kemajuan belajarnya.

Setelah draft media pembelajaran tersebut selesai disusun, langkah selanjutnya adalah mendesign dan memuat media pembelajaran agar dapat diakses melalui Smart phone ataupun computer milik mahasiswa. Dengan demikian, seluruh tahapan kegiatan pembelajaran dapat dilalui mahasiswa setiap saat tanpa tergantung pada kegiatan tatap muka di kelas.

Media pembelajaran ini dimuat di Edmodo. Rismayanti (2012) menyampaikan bahwa Edmodo adalah platform media sosial yang memiliki tampilan serta fitur menyerupai Facebook, media ini sering disebut sebagai Facebook untuk sekolah yang memiliki banyak fungsi sesuai dengan kebutuhan. Uraian tersebut menjadi salah satu alasan dipilihnya Edmodo sebagai media sosial yang memuat media pembelajaran Digital Daily Assessment. Sebagaimana kita ketahui bersama bahwa Facebook adalah salah satu media sosial yang sangat dikenal oleh masyarakat, hampir semua orang memahami cara mengaplikannya. Tampilan dan fitur Edmodo hampir sama dengan Facebook, dengan demikian diharapkan mahasiswa dapat mengaplikasikan media pembelajaran ini dengan mudah tanpa harus menyediakan waktu khusus untuk mempelajari cara pengaplikasiannya. Alasan lainnya adalah Edmodo dapat mengajarkan siswa untuk bertanggung jawab mengatur kegiatan belajar mereka dengan sistem keamanan terjamin (Rismayanti, 2012). Dengan demikian diharapkan dapat memberdayakan keterampilan metakognitif mahasiswa.

\section{Tahap Develop}

Tahapan selanjutnya adalah develop. Kegiatan yang dilakukan pada tahap ini yaitu mengujikan draft media pembelajaran yang sudah dirancang kepada para ahli dan kepada mahasiswa. Tahapan ini terdiri dari proses validasi ahli materi, ahli media, praktisi dan uji keterbacaan oleh mahasiswa. Berikut ini akan dibahas hasil yang diperoleh dari hasil validasi.

Berdasarkan Tabel 3 ringkasan hasil validasi ahli materi morfologi tumbuhan dapat diketahui bahwa hasil penilaian media pembelajaran Digital Daily Assessment oleh ahli materi menunjukkan nilai rata-rata 95,14\%. Menurut Suwastono (2011), nilai tersebut sangat valid. Dengan demikian, jika ditinjau dari kelayakan materi, maka media pembelajaran ini dapat digunakan. Berikut ini masukan yang diberikan oleh ahli materi. Pertama, materi yang tercantum pada media pembelajaran telah sesuai dengan yang ditemui dalam kehidupan sehari-hari (kontekstual), namun bisa ditambahkan lagi jenis daun dan akar dari tumbuhan lain yang juga ditemui dalam kehidupan sehari-hari. Kedua, pada kegiatan pengelompokan daun, sebaiknya ditambahkan petunjuk agar dapat membantu mahasiswa dalam menyelesaikan soal.

Tabel 4 menunjukkan data ringkasan hasil validasi ahli media pembelajaran. Berdasarkan tabel tersebut dapat diketahui bahwa hasil penilaian media pembelajaran Digital Daily Assessment oleh ahli media menunjukkan nilai rata-rata $97,92 \%$. Menurut Suwastono (2011), nilai ini sangat valid. Dengan demikian, apabila ditinjau dari kelayakan media, maka media pembelajaran ini dapat digunakan. Berikut ini masukan yang diberikan oleh ahli materi. Pertama, sebaiknya media dikembangkan lebih menarik lagi, misalnya layout dibuat agar lebih menarik. Kedua, soal-soal yang dikembangkan dalam mengakomodasi pengembangan kemampuan berpikir mahasiswa perlu ditingkatkan atau dikembangkan lebih lanjut.

Tabel 5 menunjukkan data ringkasan hasil validasi praktisi. Melalui tabel tersebut kita dapat mengetahui bahwa nilai rata-rata yang diberikan oleh praktisi untuk media pembelajaran Digital Daily Assessment adalah 97,25\%. Hal ini menunjukkan bahwa media pembelajaran ini sangat valid 
(Suwastono, 2011). Dengan demikian, media pembelajaran ini layak digunakan untuk kegiatan pembelajaran.

Berdasarkan Tabel 6 hasil uji keterbacaan oleh mahasiswa program studi pendidikan biologi diketahui bahwa nilai rata-rata media pembelajaran adalah 93,4\%. Menurut Suwastono (2011) media pembelajaran ini sangat valid. Jadi, media pembelajaran ini sudah layak digunakan untuk kegiatan pembelajaran.

Hasil kegiatan validasi dan uji keterbacaan menunjukkan bahwa media pembelajaran Digital Daily Assessment layak digunakan untuk kegiatan pembelajaran mata kuliah Morfologi Tumbuhan. Media pembelajaran ini dirancang dengan memperhatikan aspek-aspek keterampilan metakognitif. Oleh karena itu, diharapkan media pembelajaran ini dapat memberdayakan keterampilan metakognitif mahasiswa. Dengan meningkatnya keterampilan metakognitif mahasiswa, diharapkan pula hasil belajar kognitif mahasiswa juga akan meningkat.

\section{KESIMPULAN DAN SARAN Kesimpulan}

Berdasarkan hasil validasi dari ahli materi, ahli media, dan uji keterbacaan diketahui bahwa media pembelajaran Digital Daily Assessment layak untuk digunakan. Hal ini ditunjukkan dari nilai yang diperoleh dari validasi oleh ahli materi adalah $95,14 \%$, yang berarti sangat valid, nilai validasi dari ahli media adalah $97,92 \%$, yang berarti sangat valid, nilai validasi dari praktisi adalah $97,25 \%$, dan nilai yang diperoleh dari hasil uji keterbacaan adalah 93,4\%, yang berarti sangat valid.

\section{Saran}

Hasil validasi serta uji coba keterbacaan menunjukkan bahwa media pembelajaran Digital Daily Assessment sangat valid. Akan tetapi, perlu dilakukan pengujian media pembelajaran ini lebih lanjut untuk mengetahui efektivitas media pembelajaran tersebut terhadap pemberdayaan keterampilan metakognitif dan hasil belajra kognitif bagi mahasiswa Program Studi Pendidikan Biologi IKIP Budi Utomo.

\section{DAFTAR RUJUKAN}

Barnes, S. F. 2007. Essential Life Skills. (Online).

(http://interwork.sdsu.edu/elip/ bve/documents/EssentialLifeSkills_000 .pdf, (diakses tanggal 14 Juni 2016)

Corebima, A. D. 2009. Metacognitive Skill Measurement Integrated in Achievement Test. (Online) (http://www.recsam.edu.my/cosmed/co smed09/AbstractsFullPapers2009/Abst ract/Science\%20Paralle1\%20PDF/Full \%20Paper/01.pdf, diakses tanggal 25 Juni 2013)

Lestari, P. B. \& Wijayanti, T. 2016. Pengaruh Model Reciprocal Teaching Dipadukan dengan Think Pair Share terhadap Kemampuan Metakognisi Mahasiswa MK Mikrobiologi IKIP Budi Utomo. JEMS (Jurnal Edukasi Matematika dan Sains), 4 (1): 36-42.

Livingston, J. 1997. Metacognition: An Overview. (Online). (http: //www.gse.buffalo.edu/fas/shuell/CEP5 64/Metacog.html, diakses tanggal 4 Januari 2014)

Rismayanti. 2012. Mengenal Lebih Dekat Edmodo (Online) (), (diakses tanggal 1 Oktober 2018)

Scott. The Futures of Learning 2: What kind of Learning for The $21^{\text {st }}$ Century (Online)

(http://unesdoc.unesco.org/images/002 4/002429/242996E.pdf, (diakses tanggal 20 Oktober 2016)

Setiawan, D. C. 2015. Penerapan Strategi Pembelajaran Kooperatif Reciprocal Teaching (RT) untuk Meningkatkan Kemampuan Metakognitif Mahasiswa IKIP Budi Utomo Malang. Saintifika, 17 (2): 40-46

Suwastono, A. 2011. Pengembangan Pembelajaraan E-learning Berbass Moodle pada Mata Kuliah Penginderaan Jauh S1 Jurusan Geografi Universitas Negeri Malang: Tesis tidak diterbitkan. Malang: PPs 
Pangestuti \& Prasmala, Pengembangan Media Pembelajaran ...

UM.

Thiagarajan, et al. (1974). Instructional

Development for Training Teachers of
Exceptional Children. Washington D.C.: National Center for Improvement of Educational Systems. 